\title{
Trend Analyses of Parameters of Equations for Sender Fairness Proportion Achievable in Ubicomp MANETs Using Location-Aware Transmission.
}

\author{
M. Kaleem GALAMALI, Assoc. Prof Nawaz MOHAMUDALLY
}

\begin{abstract}
Research and development proper to the control of energy consumption in ubicomp is well ongoing and also concerns MANET transmission [76]. It still is undisputed that this field is underdeveloped. Ubicomp hardware and battery power also are considered constrained. A recent study was conducted [25] to quantify and model the Sender Fairness Proportion (S_FP) achievable for CBRs for node densities of 7 until 56. The corresponding model was described as a combination of linear and exponential trends.
\end{abstract}

In this paper, the successive plane of investigation is stated as: "What are the trends of variation observable within each parameter of the equations of curves obtained for metric S_FP [25] over varying node densities?”

It is advisable that the behaviour of each constituent of fitting models for metric S_FP be adequately learnt in form of mathematical notions. This will, in turn, assist studying in further predictability features. This exercise will be quite bulky and will necessitate lots of discord resolution within the research community. The outcome laid forward in this paper will aid ubicomp researchers in more prosperous development of MANET features and algorithmic support for energy management in ubicomp topographies. Such directions may yield significantly different battery designs and surrogate devices needed. This paper is a follow-up of previous work [1-40].

Key terms: Ubicomp- Ubiquitous Computing, MAUCMobile and Ubiquitous Computing, MANET- Mobile Adhoc Network, CBR- Constant Bit Rate, S_FP-Sender Fairness Proportion.

M. Kaleem GALAMALI,

University of Technology Mauritius (student)

Mauritius

Assoc. Prof Nawaz Mohamudally

University of Technology Mauritius, Mauritius

\section{Introduction}

Ubicomp topographies may be meagrely equipped with networking devices. This degree of equipment may vary from one topography to another. In such circumstances, MANET transmission strategies are welcome as beneficial solutions. In MANETs, following transmission load division, the element of Fairness crops up. Many methods of studying Fairness are possible, including metrics development and analysis. Such a work was produced [25], in which the behaviour of metric S_FP was portrayed in two parts:

- Previous to the maximum point, the linear tendency is visible of form:

$$
F(x)=d * x+f
$$

- As from the peak value onwards, the exponentially decreasing trend is visible of form:

$$
G(x)=a * \exp (b *(x-c))
$$

Here, the equations of the model have necessitated 5 parameters: $a, b, c, d$ and $f$. the next clarification for metric S_FP required is the formulation of model equations for parameters of equations specified above.

The key contributions of this paper is the development of the trend of variation for each parameter of the equations included in the model for metric S_FP presented in a recent paper [25] from which tables 1(a) and 1(b) are re-employed here. The mathematical methods developed here, could be programmed into software simulators, giving a utility means for designers to more constructively investigate the evolution and predictability of ubicomp features, hence enabling the refinement of provisioning for future ubicomp architecture. The rest of this paper is organised as follows: section 2- Parameter Trend Analysis- Metric S_FP, section 3- Conclusion and References.

\section{Parameter Trend Analysis - Metric Min_FP. \\ 2.0 General Procedure Adopted.}

The initial step is to plot the tabulated data for each parameter of the equations for the model for S_FP onto gnuplot. The following step is to undertake graphical analyses and relating the general observations reachable. The next step is to explore the applicability of selected hypothetical equations of fit. For all parameters, criterion for best fit is value of least reduced chi-square. The additional criterion for parameters b, c and d is most likely extendability at node numbers 80,100 and 120 . The last step is to write down the corresponding parameter values for each S_FP parameter equation. 
Proc. of the Seventh International Conference On Advances in Computing, Electronics and Electrical Technology - CEET 2017. Copyright (C) Institute of Research Engineers and Doctors. All rights reserved.

ISBN: 978-1-63248-126-9 doi: 10.15224/ 978-1-63248-126-9-14

\subsection{Trend Analysis - S FP parameter " $a$ ”.}

Generally, a straight line with a very small negative gradient is depicted. This is more convincing for plots as from node number 16 onwards. Previous to node number 16, the plots are quite scattered and show the possibility that if the "fit" command in gnuplot is reworked with different starting points, other parameter values are obtained, which may have greater conformance to the line obtained.

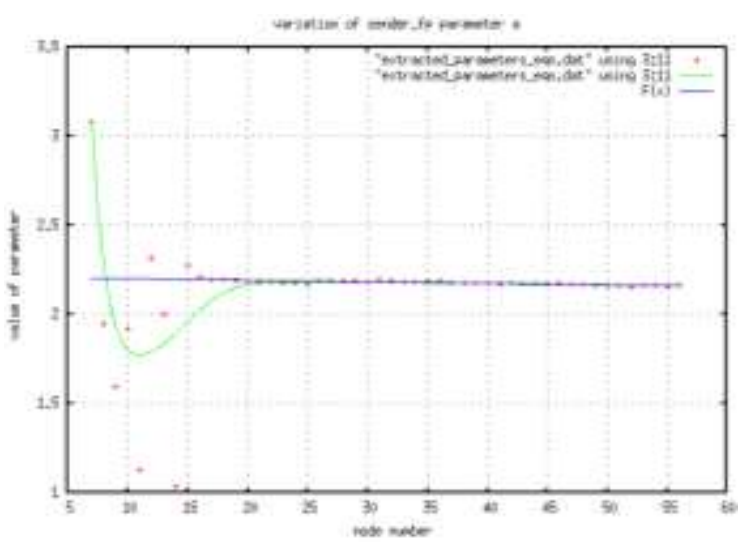

Figure 1: S_FP parameter a

The applicable equation here has been:

$$
\begin{aligned}
& F(\mathrm{x})=\mathrm{d} \star \mathrm{x}+\mathrm{f} \\
& \text { Ch_sq }=4.31608\left(\mathrm{e}^{-06}\right)
\end{aligned}
$$

The parameters for best fit are: $d=-0.000901722, f=$ 2.21114

\subsection{Trend Analysis - S FP parameter " $b$ ”.}

Generally the curve depicts a decreasing tendency at a decreasing rate. A slight oscillation is also visible but is not consistent throughout and is hence neglected. The $\mathrm{y}$-axis intervals are also very small.

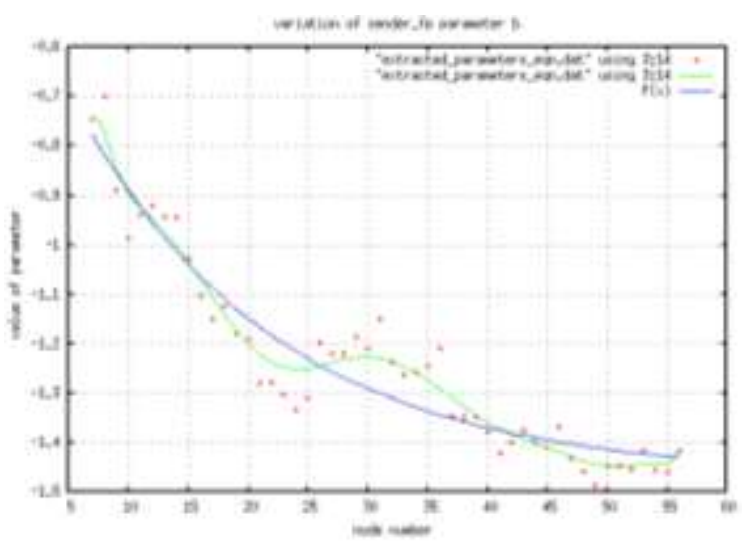

Figure 2: S_FP parameter b

The potentially applicable equations of trend are:

$$
\begin{array}{rl}
\text { 1. } F(x)=a * \exp (b *(x-c))+d \\
\text { Ch_sq }=0.00432237 & F(80)=-1.4586672 \\
F(100)=-1.4649791 & F(120)=-1.466906736 \\
\text { 2. } F(x)=a x^{*} * \exp & (b *(x-c))+d
\end{array}
$$

$$
\begin{array}{rl}
\text { Ch_sq }=0.0047054 & \\
\text { 3. } \mathrm{F}(\mathrm{x})=\mathrm{a} * \mathrm{x} * \exp & (\mathrm{b} *(\mathrm{x}-\mathrm{c}))+(\mathrm{d} / \mathrm{x}) \\
\text { Ch_sq }=0.006 & \\
\mathrm{~F}(\mathrm{x})=\mathrm{a} * \exp & (\mathrm{b} *(\mathrm{x}-\mathrm{c}))+(\mathrm{d} / \mathrm{x}) \\
\text { Ch_sq }=0.00368871 & \mathrm{~F}(80)=-1.614 \\
\mathrm{~F}(100)=-1.738 & \mathrm{~F}(120)=-1.866
\end{array}
$$

\section{Choice of best fit for $S \_F P$ parameter $b$}

The equation in part 1 above has been selected because of best extendability feature even if the reduced chisquare value obtained is not smallest. The parameters for best fit are:

$\mathrm{a}=1.03925, \mathrm{~b}=-0.059307, \mathrm{c}=0.0869711, \mathrm{~d}=$ 1.46775

\subsection{Trend Analysis - S_FP parameter "c".}

Here also, an observation similar to that in section 2.1 is made. Mostly as from node number 16 onwards, a straight line is found. Similar observation as in section 2.1 applies here for node number previous to 16 .

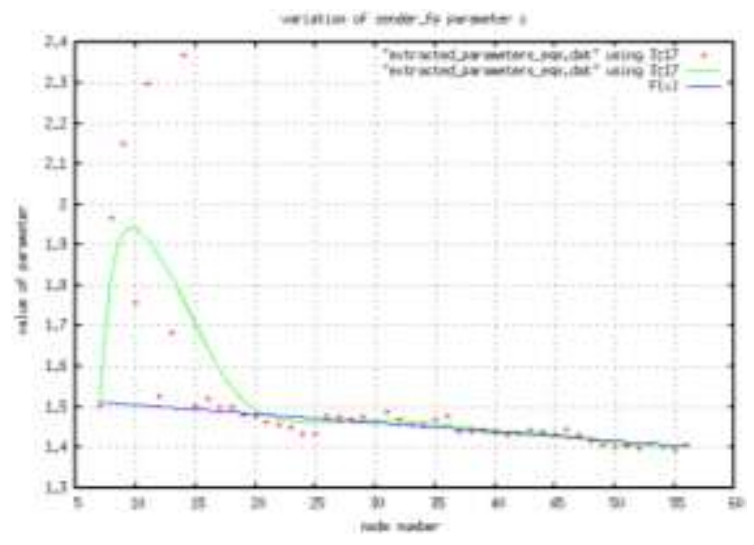

Figure 3: S_FP parameter c

The potentially applicable equations of trend are:

$$
\begin{array}{rl}
\text { 1. } F(x)=a * \exp (b *(x-c))+d \\
\text { Ch_sq }=0.0260573 & F(80)=1.400538261 \\
F(100)=1.400084988 & F(120)=1.400017657 \\
\text { 2. } \quad \mathrm{F}(\mathrm{x})=\mathrm{d} * \mathrm{x}+\mathrm{f} & \\
\text { Ch_sq }=0.000255464 & \mathrm{~F}(80)=1.350162528 \\
\mathrm{~F}(100)=1.305815334 & \mathrm{~F}(120)=1.261468141
\end{array}
$$

\section{Choice of best fit for S_FP parameter c}

The equation in part 2 above has been selected because of both smallest reduced chi-square value obtained. The parameters for best fit are:

$\mathrm{d}=-0.00221736, \mathrm{f}=1.52755$

\subsection{Trend Analysis - S FP parameter " $d$ ”.}

The curve obtained here depicts an oscillation. However, the oscillation is not cleanly uniform nor symmetrical. 


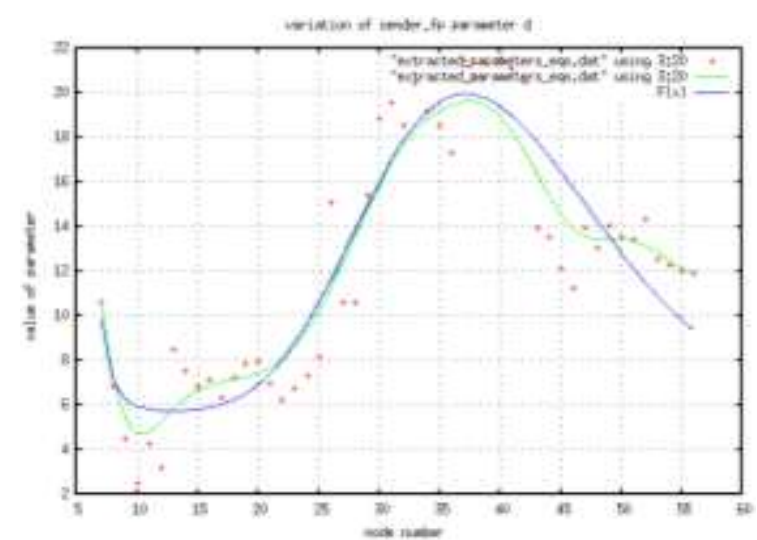

Figure 4: S_FP parameter d

The potentially applicable equations of trend are:

$$
\begin{aligned}
& \text { 1. } F(x)=\left(\left(\left(a * x^{f}\right)+d\right) /(\exp ((\right. \\
& \mathrm{b} \star \mathrm{x})+\mathrm{c})) \text { ) }+\mathrm{g} \\
& \text { Ch_sq }=5.67444 \\
& 2 \cdot F(x)=\left(\left(\left(a * x^{f}\right)+d\right) /(\exp ((\right. \\
& \left.\left.\left.\left.\mathrm{b} \star \mathrm{x}^{\mathrm{h}}\right)+\mathrm{C}\right)\right)\right)+\mathrm{g} \\
& \text { Ch_sq }=5.39481 \quad \mathrm{~F}(80)=5.7796 \\
& \mathrm{~F}(100)=5.7016855 \quad \mathrm{~F}(120)=5.700189
\end{aligned}
$$

\section{Choice of best fit for S_FP parameter d}

The equation in part 2 above has been selected because of both smallest reduced chi-square value obtained. The parameters for best fit are:

$\mathrm{a}=5.21974\left(\mathrm{e}^{-24}\right), \mathrm{b}=2.66342, \mathrm{c}=-9.9614, \mathrm{~d}=$ $4.5938, \mathrm{f}=21.5208, \mathrm{~g}=5.70017, \mathrm{~h}=0.6833$

\subsection{Trend Analysis - S FP parameter "f".}

The curve obtained here has a minimum point and a maximum point. The curve is not cleanly uniform nor symmetrical.

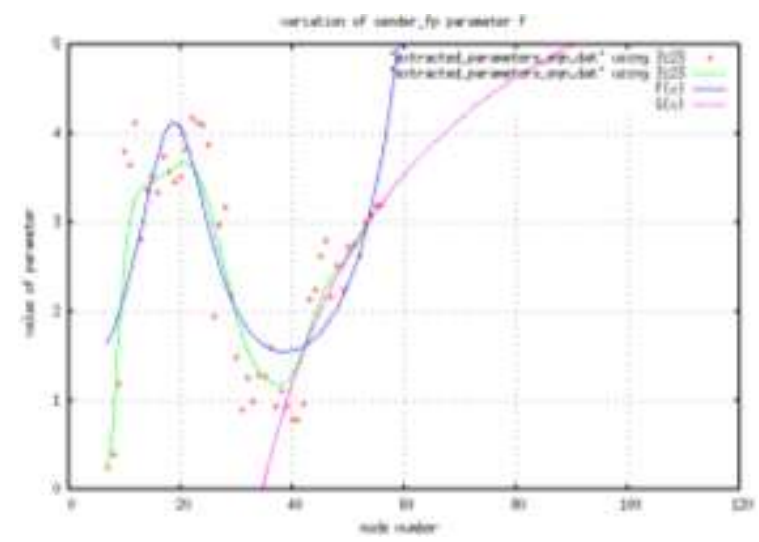

Figure 5: S_FP parameter $f$

The predictability equation has been broken into two.

i. For node number 7 till 50, the applicable equation is (appears in blue in soft copy)

$$
\begin{aligned}
& \mathrm{F}(\mathrm{x})=\left(1 /\left(\mathrm{a} * \mathrm{x}^{\mathrm{f}}+\mathrm{d}\right)\right) *(\exp \\
& \left.\left(\left(\mathrm{b} * \mathrm{x}^{\mathrm{h}}\right)+\mathrm{c}\right)\right)
\end{aligned}
$$

$$
\text { Ch_sq }=0.54829
$$

The parameters of fit are:

$\mathrm{a}=1.68854\left(\mathrm{e}^{-10}\right), \mathrm{b}=0.024204, \mathrm{c}=-0.182$ $282, \mathrm{~d}=0.762797, \mathrm{f}=7.35669, \mathrm{~h}=1.45938$.

ii. For node number 50 onwards, the applicable equation is (purple in soft copy)

$$
\begin{gathered}
G(x)=(i / \log (k \star x))+1 \\
\text { Ch_sq }=0.015916 \\
G(100)=5.29161
\end{gathered}
$$

The parameters of fit are: $\mathrm{i}=-13.1202, \mathrm{k}=$ $0.093219,1=11.1689$

\section{Conclusion.}

This research endeavour was intended to and has achieved the development of applicable models of trends of the parameters of equations for the metric S_FP in a MANET topography of $300 \times 300 \mathrm{~m}^{2}$. The models detailed here are intrinsically mathematical, and of graded complexity levels. These will assist in more profound studies of MANETs for MAUC. Such development will lead towards the formulation of processing algorithms to be applied in simulators for more specific studies of MANETs. This experiment has been conducted in gnuplot. Criteria for selection of best fit have been mostly value of least reduced chi-square and partly best extendability at higher node numbers.

The fair assumptions put forward in a prior paper [25] are continued in this paper also. Gnuplot is also taken as suitable for the extent of this study.

Further work identified remain: formulating methods of predictability for metric S_FP and its trend and reporting distinct observations of certain critical values identified.

\section{References}

[1] M. Kaleem GALAMALI, Assoc. Prof Nawaz MOHAMUDALLY, Towards Dependable Pervasive Systems-A Position and Vision Paper, CEET 2014

[2] M. Kaleem GALAMALI, Assoc. Prof Nawaz MOHAMUDALLY, Model of Energy Savings achievable with Location-aware Node-to-Node Transmission in UbiComp , CEET 2014

[3] M. Kaleem GALAMALI, Assoc. Prof Nawaz MOHAMUDALLY, Model of Energy Savings achievable with Location-aware Node-to-Node Transmission in UbiComp Using Location Refresh Intervals, CEET 2014

[4] M. Kaleem GALAMALI, Assoc. Prof Nawaz MOHAMUDALLY, Model of Energy Savings achievable with Location-aware Transmission in UbiComp Using Relays, CEET 2014

[5] M. Kaleem GALAMALI, Assoc. Prof Nawaz MOHAMUDALLY, Mathematical modeling of need of exact number of relays to ensure seamless mobility in mobile computing, CEET 2014 
[6] M. Kaleem GALAMALI, Assoc. Prof Nawaz MOHAMUDALLY, Modelling of need for multiple relays for ensuring seamless mobility, CEET 2014

[7] M. Kaleem GALAMALI, Assoc. Prof Nawaz MOHAMUDALLY, Investigation of prominence of placements of relays in a ubicomp topography,

[8] M. Kaleem GALAMALI, Assoc. Prof Nawaz MOHAMUDALLY, Model of energy savings achievable with location-aware transmission in ubicomp using optimised number of relays.

[9] M. Kaleem GALAMALI, Assoc. Prof Nawaz MOHAMUDALLY, Investigation of Prominence of Placements of Optimised Number of Relays in a Ubicomp Topography using Location-Aware Transmission, CEET 2015.

[10] M. Kaleem GALAMALI, Assoc. Prof Nawaz MOHAMUDALLY, Extending Node Battery Availability in Ubicomp with Location-Aware Transmission, CEET 2015.

[11] M. Kaleem GALAMALI, Assoc. Prof Nawaz MOHAMUDALLY, Extending Node Battery Availability in Ubicomp with Location-Aware Transmission using Location Refresh Intervals, CEET 2015.

[12] M. Kaleem GALAMALI, Assoc. Prof Nawaz MOHAMUDALLY, Extending Node Battery Availability in Ubicomp with Location-Aware Transmission using Uniformly Placed Relays, CEET 2015.

[13] M. Kaleem GALAMALI, Assoc. Prof Nawaz MOHAMUDALLY, Extending Node Battery Availability in Ubicomp with Location-Aware Transmission Using Optimally Placed Relays, CEET 2015.

[14] M. Kaleem GALAMALI, Assoc. Prof Nawaz MOHAMUDALLY, Model of Sender Node Energy Savings Achievable with Location-Aware MANET Transmission in Ubicomp. ACCN 2016

[15] M. Kaleem GALAMALI, Assoc. Prof Nawaz MOHAMUDALLY, Model of Overall Node Energy Savings Achievable with Location-Aware MANET Transmission in Ubicomp. ACCN 2016

[16] M. Kaleem GALAMALI, Assoc. Prof Nawaz MOHAMUDALLY, Model of Sender Node Extra Energy Savings Achievable in MANET Against Direct Node-toNode Transmission Using Location-Aware Transmission in Ubicomp. ACCN 2016

[17] M. Kaleem GALAMALI, Assoc. Prof Nawaz MOHAMUDALLY, Model of Overall Node Extra Energy Savings Achievable in MANET against Direct Node-toNode Transmission Using Location-Aware Transmission in Ubicomp. ACCN 2016

[18] M. Kaleem GALAMALI, Assoc. Prof Nawaz MOHAMUDALLY, Model of Energy Consumption Ratio Achievable in MANET Using Location-Aware Transmission in Ubicomp. ACCN 2016

[19] M. Kaleem GALAMALI, Assoc. Prof Nawaz MOHAMUDALLY, Model of Minimum Energy Consumption Ratio Achievable in MANET Using LocationAware Transmission in Ubicomp. ACCN 2016

[20] M. Kaleem GALAMALI, Assoc. Prof Nawaz MOHAMUDALLY, Model of Maximum Energy Consumption Ratio Achievable in MANET Using LocationAware Transmission in Ubicomp. ACCN 2016

[21] M. Kaleem GALAMALI, Assoc. Prof Nawaz MOHAMUDALLY, Model of Overall Energy Consumption Fairness Ratio Achievable in MANET Using LocationAware Transmission in Ubicomp. ACCN 2016

[22] M. Kaleem GALAMALI, Assoc. Prof Nawaz MOHAMUDALLY, Model of Overall Energy Consumption Fairness Proportion Achievable in MANET Using LocationAware Transmission for Ubicomp, CEET 2016

[23] M. Kaleem GALAMALI, Assoc. Prof Nawaz MOHAMUDALLY, Model of Minimum Fairness Proportion Achievable in MANET Using Location-Aware Transmission for Ubicomp, CEET 2016

[24] M. Kaleem GALAMALI, Assoc. Prof Nawaz MOHAMUDALLY, Model of Maximum Fairness Proportion Achievable in MANET Using Location-Aware Transmission for Ubicomp, CEET 2016

[25] M. Kaleem GALAMALI, Assoc. Prof Nawaz MOHAMUDALLY, Model of Sender Fairness Proportion
Achievable in MANET Using Location-Aware Transmission for Ubicomp, CEET 2016

[26] M. Kaleem GALAMALI, Assoc. Prof Nawaz MOHAMUDALLY, Model of Distance Travelled by packets in MANETs using Location-Aware Transmission for Ubicomp, CEET 2016

[27] M. Kaleem GALAMALI, Assoc. Prof Nawaz MOHAMUDALLY, Model of Maximum CBR Distance Travelled by packets in MANETs using Location-Aware Transmission for Ubicomp, CEET 2016

[28] M. Kaleem GALAMALI, Assoc. Prof Nawaz MOHAMUDALLY, Model of Minimum CBR Distance Travelled by packets in MANETs using Location-Aware Transmission for Ubicomp, CEET 2016

[29] M. Kaleem GALAMALI, Assoc. Prof Nawaz MOHAMUDALLY, Model of Range CBR Distance Experienced by Transmissions in MANETs using LocationAware Transmission for Ubicomp, CEET 2016

[30] M. Kaleem GALAMALI, Assoc. Prof Nawaz MOHAMUDALLY, Trend Analyses of Parameters of Equations for Sender Node Energy Savings Achievable in ubicomp MANETs using Location-Aware Transmission, ACCN 2017.

[31] M. Kaleem GALAMALI, Assoc. Prof Nawaz MOHAMUDALLY, Trend Analyses of Parameters of Equations for Overall Node Energy Savings Achievable in ubicomp MANETs using Location-Aware Transmission, ACCN 2017.

[32] M. Kaleem GALAMALI, Assoc. Prof Nawaz MOHAMUDALLY, Trend Analyses of Parameters of Equations for Sender Node Extra Energy Savings Achievable in MANET against Direct Node-to-Node Location-Aware Transmission, ACCN 2017.

[33] M. Kaleem GALAMALI, Assoc. Prof Nawaz MOHAMUDALLY, Trend Analyses of Parameters of Equations for Overall Nodes Extra Energy Savings Achievable in MANET against Direct Node-to-Node Location-Aware Transmission, ACCN 2017.

[34] M. Kaleem GALAMALI, Assoc. Prof Nawaz MOHAMUDALLY, Trend Analyses of Parameters of Equations for Energy Consumption Ratio Achievable in Ubicomp MANET Using Location-Aware Transmission, ACCN 2017.

[35] M. Kaleem GALAMALI, Assoc. Prof Nawaz MOHAMUDALLY, Trend Analyses of Parameters of Equations for Minimum Energy Consumption Ratio Achievable in Ubicomp MANETs Using Location-Aware Transmission, ACCN 2017.

[36] M. Kaleem GALAMALI, Assoc. Prof Nawaz MOHAMUDALLY, Trend Analyses of Parameters of Equations for Maximum Energy Consumption Ratio Achievable in Ubicomp MANETs Using Location-Aware Transmission, ACCN 2017.

[37] M. Kaleem GALAMALI, Assoc. Prof Nawaz MOHAMUDALLY, Trend Analyses of Parameters of Equations for Overall Fairness Ratio Achievable in Ubicomp MANETs Using Location-Aware Transmission, ACCN 2017.

[38] M. Kaleem GALAMALI, Assoc. Prof Nawaz MOHAMUDALLY, Trend Analyses of Parameters of Equations for Energy Consumption Fairness Proportion Achievable in Ubicomp MANETs Using Location-Aware Transmission, CEET 2017

[39] M. Kaleem GALAMALI, Assoc. Prof Nawaz MOHAMUDALLY, Trend Analyses of Parameters of Equations for Minimum Fairness Proportion Achievable in Ubicomp MANETs Using Location-Aware Transmission, CEET 2017

[40] M. Kaleem GALAMALI, Assoc. Prof Nawaz MOHAMUDALLY, Trend Analyses of Parameters of Equations for Maximum Fairness Proportion Achievable in Ubicomp MANETs Using Location-Aware Transmission, CEET 2017

[41] Markus Bylund and Zary Segall, Towards seamless mobility with personal servers, 2004.

[42] Masugi Inoue, Mikio Hasegawa, Nobuo Ryoki and Hiroyuki Morikawa, Context-Based Seamless Network and Application Control, 2004

[43] Xiang Song, Umakishore Ramachandran, MobiGo: A 
Middleware for Seamless Mobility, College of Computing Georgia Institute of Technology, Atlanta, GA, USA, August 2007

[44] Budzisz, Ferrús, R., Brunstrom A., Grinnemo, K, Fracchia, R., Galante, G., and Casadevall, F. Towards transport-layer mobility: Evolution of SCTP multihoming, March 2008

[45] Paul Dourish \& Genevieve Bell, Divining a digital future, 2011.

[46] Xiang Song, Seamless Mobility In Ubiquitous Computing Environments, PhD Thesis, Georgia Institute of Technology, August 2008

[47] Kevin O Mahony, Jian Liang, Kieran Delaney, User-Centric Personalization and Autonomous Reconfiguration Across Ubiquitous Computing Environments, NIMBUS Centre Cork Institute of Technology, Cork, Ireland, UBICOMM 2012

[48] Pablo Vidales, Seamless mobility in 4G systems, Technical Report, University of Cambridge, Computer Laboratory, Number 656, November 2005

[49] João Pedro Sousa and David Garlan, Aura: An Architectural Framework for User Mobility in Ubiquitous Computing Environments, School of Computer Science, Carnegie Mellon University, USA, August 2002

[50] Dennis Lupiana, Ciaran O’Driscoll, Fredrick Mtenzi, Defining Smart Space in the Context of Ubiquitous Computing, Dublin Institute of Technology, Ireland, Special Issue on ICIT 2009 Conference - Web and Agent Systems, 2009

[51] N.S.V.Shet1, Prof.K.Chandrasekaran2 and Prof. K.C.Shet3, WAP Based Seamless Roaming In Urban Environment with Wise Handoff Technique, International Journal of UbiComp (IJU), Vol.1, No.4, October 2010

[52] Yipeng Yu Dan He Weidong Hua Shijian Li Yu Qi Yueming Wang Gang Pan, FlyingBuddy2: A Braincontrolled Assistant for the Handicapped, Zhejiang University, UbiComp'12, September 5-8, 2012.

[53] Jing Su, James Scott, Pan Hui, Jon Crowcroft, Eyal de Lara Christophe Diot, Ashvin Goel, Meng How Lim, and Eben Upton, Haggle: Seamless Networking for Mobile Applications, 2007

[54] Rui Han, Moustafa M. Ghanem, Li Guo, Yike Guo*, Michelle Osmond, Enabling cost-aware and adaptive elasticity of multi-tier cloud applications, Future Generation Computer Systems, 2012

[55] Byrav Ramamurthy, K. K. Ramakrishnan, Rakesh K. Sinha, Cost and Reliability Considerations in Designing the NextGeneration IP over WDM Backbone Networks, 2012.

[56] Bhavish Aggarwal, Aditya Akella, Ashok Anand, Athula Balachandran, Pushkar Chitnis, Chitra Muthukrishnan, Ram Ramjee and George Varghese, EndRE: An End-System Redundancy Elimination Service for Enterprises, NSDI 2010, San Jose, CA

[57] Ashok Anand, Vyas Sekar and Aditya Akella, SmartRE: An Architecture for Coordinated Network-wide Redundancy Elimination, SIGCOMM 2009, Barcelona, Spain

[58] John Breeden II, "Smart-phone battery life could double without better batteries", Nov 14, 2012

[59] Andy Boxall, "When will your phone battery last as long as your kindle", December 5, 2012.

[60] Imielinski, T. and Navas, J.C. (1999). GPS-based geographic addressing, routing, and resource discovery. Comms. ACM, Vol. 42, No. 4, pp. 86-92.

[61] Hightower, J. and Borriello, G. (2001). Location Systems for Ubiquitous Computing. IEEE Computer, Vol. 34, No. 8, August, pp. 57-66.

[62] Harter, A., Hopper, A., Steggles, P., Ward, A. and Webster, P. (2002). The Anatomy of a Context-Aware Application. Wireless Networks, Vol. 8, No. 2-3, Mar-May, pp. 187-197.

[63] Hightower, J., Brumitt, B. and Borriello, G. (2002). The Location Stack: A Layered Model for Location in Ubiquitous Computing. Proceedings of the 4th IEEE Workshop on Mobile Computing Systems \& Applications (WMCSA 2002), Callicoon, NY, USA, June, pp. 22-28.

[64] Graumann, D., Lara, W., Hightower, J. and Borriello, G. (2003). Real-world implementation of the Location Stack: The Universal Location Framework. Proceedings of the 5th
IEEE Workshop on Mobile Computing Systems \& Applications (WMCSA 2003), Monterey, CA, USA, October, pp. 122-128.

[65] Ko, Y., \& Vaidya, N. H. (2000). Location-aided routing (LAR) in mobile ad hoc networks. Wireless Networks, 6(4), 307-321.

[66] Liao, W.-H., Tseng, Y.-C., \& Sheu, J.-P. (2001). GRID: a fully location-aware routing protocol for mobile ad hoc networks. Telecommunication Systems, 18(1), 37-60.

[67] Kuhn, F., Wattenhofer, R., Zhang, Y., \& Zollinger, A. (2003). Geometric ad-hoc routing: of theory and practice. In Proceedings of the ACM (PODC'03) (pp. 63-72).

[68] Jiang, X., \& Camp, T. (2002). Review of geocasting protocols for a mobile ad hoc network. In Proceedings of the Grace Hopper Celebration (GHC).

[69] Ko, Y. \& Vaidya, N. H. (1999). Geocasting in mobile ad hoc networks: location-based multicast algorithms. In Proceedings of the IEEE (WMCSA'99) (pp. 101).

[70] Mauve, M., Fuler, H., Widmer, J., \& Lang, T. (2003). Position-based multicast routing for mobile ad-hoc networks (Technical Report TR-03-004). Department of Computer Science, University of Mannheim.

[71] Xu, Y., Heidemann, J., \& Estrin, D. (2001). Geographyinformed energy conservation for adhoc routing. In Proceedings of the ACM/IEEE (MOBICOM'01) (pp. 70-84).

[72] Hu, Y.-C., Perrig, A., \& Johnson, D. (2003). Packet leashes: a defense against wormhole attacks in wireless ad hoc networks. In Proceedings of the INFOCOM’ 03 (pp. 19761986).

[73] Patwari, N., Hero III, A. O., Perkins, M., Correal, N. S., \& O’Dea, R. J. (2003). Relative location estimation in wireless sensor networks. IEEE Transactions on Signal Processing, 51(8), 2137-2148.

[74] Baldauf, M., Dustdar, S., \& Rosenberg, F. (2007). A Survey on Context Aware Systems. International Journal of Ad Hoc and Ubiquitous Computing, Inderscience Publishers. forthcoming. Pre-print from: http://www.vitalab.tuwien.ac.at/ florian/papers/ijahuc2007.pdf

[75] Hong, D., Chiu, D.K.W., \& Shen, V.Y. (2005). Requirements elicitation for the design of context-aware applications in a ubiquitous environment. In Proceedings of ICEC'05 (pp. 590-596).

[76] Neeraj Tantubay, Dinesh Ratan Gautam and Mukesh Kumar Dhariwal, A Review of Power Conservation in Wireless Mobile Ad hoc Network (MANET)", International Journal of computer Science Issues, Vol 8, Issue 4, No 1, July 2011.

[77] Wenrui Zhao, Mostafa Ammar and Ellen Zegura, "A Message Ferrying Approach for Data Delivery in Sparse Mobile Ad Hoc Networks", MobiHoc'04, May 24-26, 2004, Roppongi, Japan.

About Author (s)

Associate Professor Nawaz Mohamudally works at University of Technology, Mauritius (UTM) and has undertaken supervision of MPhil/PhD Students for many years.

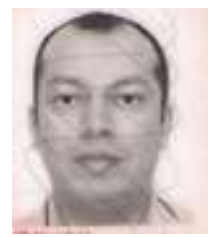

M. Kaleem Galamali is a part-time student (achieved M Phil Transfer on 28.10.2014, currently $\mathrm{PhD}$ student) at UTM under supervision of A.P. Nawaz Mohamudally. 